\title{
Hubungan Berat Badan Lahir Bayi Dengan Kejadian Stunting Pada Balita Di Wilayah Kerja Puskesmas Gunungsari Kabupaten Lombok Barat
}

\author{
Melati Inayati Albayani ${ }^{1 *}$, Raden Ahmad Dedy Mardani ${ }^{1)}$, Zaenal Arifin ${ }^{1)}$ \\ E-mail: melati.albayani@gmail.com \\ 1) Dosen STIKES YARSI Mataram
}

\begin{abstract}
ABSTRAK
Stunting merupakan masalah gizi buruk kronis yang disebabkan oleh kurangnya asupan gizi dalam waktu lama akibat pemberian makanan yang tidak sesuai dengan kebutuhan gizi. Tingginya angga kejadian stunting dan BBLR menjadi permasalahan .Tujuan penelitian ini adalah untuk menganalisis hubungan berat badan lahir dengan kejadian stunting pada balita di Puskesmas Gunungsari Lombok Barat. Jenis penelitian ini adalah metode survei analitik melalui pendekatan cross sectional dengan jumlah sampel penelitian 162 orang, diambil dengan menggunakan purposive sampling. Variabel bebasnya adalah berat badan lahir, Variabel terikat dalam penelitian ini adalah stunting. Hasil penelitian menunjukkan bahwa terdapat hubungan antara berat badan lahir dengan kejadian stunting pada balita di Puskesmas Gunungsari Lombok Barat tahun 2019 diperoleh nilai $\mathrm{P}$ value $=0,000$ dengan nilai $\mathrm{OR}=4,01$ (95\% CI: 1,99 - 8,09), yang artinya anak yang mempunyai riwayat BBLR mempunyai risiko 4,01 kali lebih besar menjadi sangat pendek dibandingkan dengan anak yang lahir tidak BBLR.
\end{abstract}

Kata Kunci: Berat Badan Lahir, Balita, BBLR, Stunting

\begin{abstract}
Stunting is a chronic malnutrition problem caused by a prolonged lack of nutrition due to feeding that is not in accordance with nutritional needs. The high incidence of stunting and LBW is a problem. The aim of this study was to analyze the relationship between birth weight and the incidence of stunting in children under five at Gunungsari Health Center, West Lombok. This type of research is an analytic survey method through a cross sectional approach with a total sample of 162 people, taken using purposive sampling. The independent variable is birth weight. The dependent variable in this study is stunting. The results showed that there was a relationship between birth weight and the incidence of stunting in children under five at Gunungsari Health Center, West Lombok in 2019, the P value $=0.000$ with OR $=4.01(95 \%$ CI: 1.99 - 8.09), which This means that children who have a history of LBW have a 4.01 times greater risk of being very short compared to children born without LBW.
\end{abstract}

Keywords: Birth Weight, Toddler, LBW, Stunting

\section{A. LATAR BELAKANG}

Masa 5 tahun pertama kehidupan atau balita merupakan masa yang sangat peka terhadap lingkungan dan berlangsung sangat pendek dan tidak dapat diulang lagi, maka masa Balita disebut "masa keemasan" (golden period), "jendela kesempatan" (window of opportunity) dan "masa kritis" (critical period) [1]. Pertumbuhan yang terjadi pada balita tidak selalu berjalan optimal, hal ini dapat dipengaruhi banyak factor. Pertumbuhan pada seorang anak merupakan investasi terbaik di masa depannya dan sangatlah penting. Indikator paling baik yang dapat digunakan 
untuk melihat status gizi anak adalah pertumbuhan. Jika pertumbuhan tidak dapat berjalan optimal maka akan menyebabkan anak menjadi stunting.

Stunting merupakan salah satu keadaan kekurangan gizi yang menjadi perhatian utama di dunia terutama di negara-negara berkembang yang memberikan dampak lambatnya pertumbuhan anak, daya tahan tubuh yang rendah, kurangnya kecerdasan dan produktifitas yang rendah [2]. Stunting ini memberikan indikasi masalah gizi yang sifatnya kronis sebagai akibat dari keadaan yang berlangsung lama, misalnya kemiskinan, perilaku hidup tidak sehat dan pola asuh/pemberian makanan yanng kurang baik dari sejak anak dilahirkan yang mengakibatkan anak menjadi pendek.

Kejadian Stunting di dunia mencapai 156 juta $(23,2 \%)$ [3]. Prevalensi Stunting di Indonesia (29\%), menurut WHO prevalensi Stunting menjadi masalah kesehatan masyarakat jika prevalensinya lebih dari 20 persen. Sedangkan di NTB, Kabupaten Lombok Barat dengan prevalensi Stunting cenderung mengalami peningkatan dari tahun $2015(12,60 \%)$, tahun $2016(12,81 \%)$ dan meningkat lagi di tahun $2017(12,86 \%)$ [4].

Riset Kesehatan Dasar (Riskesdas) 2018 yang dilakukan oleh Badan Penelitian dan Pengembangan Kesehatan (Litbangkes) menunjukkan angka yang cukup menggembirakan terkait masalah stunting. Angka stunting atau anak tumbuh pendek turun dari 37,2 persen pada Riskesdas 2013 menjadi 30,8 persen pada Riskesdas 2018.

Pemerintah Indonesia melalui program Sustainable Development Goals (SDGs) dalam targetnya diharapkan pada tahun 2030 mengakhiri segala bentuk maltnutrisi, penurunan Stunting dan wasting pada balita [5]

Berat lahir memiliki dampak yang besar terhadap pertumbuhan, perkembangan dan tinggi badan anak selanjutnya. Bayi lahir dengan BBLR akan berisiko tinggi pada morbiditas, kematian, penyakit infeksi, kekurangan berat badan dan Stunting diawal periode neonatal sampai masa kanak-kanak. Tingginya angka BBLR diperkirakan menjadi penyebab tingginya kejadian Stunting di Indonesia. BBLR menjadi faktor yang paling dominan berisiko terhadap Stunting pada anak [6].

Faktor utama penyebab Stunting yaitu asupan makanan yang tidak seimbang, berat badan lahir rendah (BBLR) dan penyakit infeksi. Sebuah penelitian menunjukkan bahwa balita dengan berat badan lahir rendah mempunyai risiko 2,3 kali lebih besar terkena Stunting dibanding balita dengan berat badan lahir normal [7].

Berdasarkan latar belakang masalah diatas maka, peneliti merasa tertarik untuk melakukan penelitian hubungan berat badan lahir dengan Stunting pada balita di Wilayah Kerja Puskesmas Gunungsari Kabupaten Lombok Barat.

\section{B. METODE PENELITIAN}

Penelitian ini adalah penelitian observasional dengan menggunakan rancangan studi cross sectional dengan pendekatan kuantitatif. Penelitian ini bertujuan untuk mengetahui hubungan berat badan lahir dengan kejadian stunting pada balita dengan melihat data sebelumnya.

Penelitian ini dilaksanakan di wilayah Kerja Puskesmas Gunungsari Kabupaten Lombok Barat. Teknik pengambilan sampel yang digunakan adalah non probability sampling dengan menggunakan tehnik Purposive sampling dengan jumlah 162 responden.

Kriteria inklusi : Anak yang mengalami stunting, Ibu balita yang bersedia menjadi responden, Ibu balita yang berdomisili di Wilayah Kerja Puskesmas Gunungsari, anak memiliki KIA lengkap. Sedangkan criteria eksklusi adalah: anak yang memiliki kelainan fisik atau cacat congenital. 


\section{HASIL DAN PEMBAHASAN}

1. Hasil Analisis Univariat

Tabel 1. Karekteristik Subyek Penelitian

\begin{tabular}{lcc}
\hline Karakteristik Dasar & \multicolumn{2}{c}{ Total } \\
\cline { 2 - 3 } Subyek Penelitian & $\mathrm{n}=162$ & $\%$ \\
\hline Usia (Bulan) & 9 & 5,6 \\
$12-18$ & 29 & 17,9 \\
$19-24$ & 58 & 35.8 \\
$25-36$ & 35 & 21,6 \\
$37-48$ & 31 & 19,1 \\
$49-60$ & & \\
Jenis Kelamin & 89 & 54,9 \\
Laki - laki & 73 & 54,1 \\
Perempuan & & \\
Riwayat BBL & 99 & 61,1 \\
BBLR & 63 & 38,9 \\
Tidak BBLR & & \\
Status stanting & & \\
(PB/TB)/U & 69 & 57,6 \\
Sangat Pendek & 93 & \\
Pendek & &
\end{tabular}

Berdasarkan hasil penelitian di atas, responden terbanyak berumur antara 25-36 bulan sebanyak 58 orang $(35,8 \%)$, dengan sebagian besar berjenis kelamin laki-laki sebanyak 89 orang $(54,9 \%)$ sebagian besar mempunyai riwayat BBLR sebanyak 99 orang $(61,1 \%)$, dan sebagian besar dengan status stunting sangat pendek sebanyak 93 orang $(57,4 \%)$.

\section{Hasil bivariat}

Tabel 2. Tabulasi silang Hubungan Berat

Badan Lahir dengan kejadian Stunting pada

balita di wilayah kerja Puskesmas Gunungsari Kabupaten Lombok Barat tahun 2019.

\begin{tabular}{|c|c|c|c|c|c|c|c|}
\hline \multicolumn{5}{|c|}{ Kategori Sangat PendekPendek } & \multirow{2}{*}{$\Sigma$} & \multirow{2}{*}{$\%$} & \multirow{2}{*}{$\begin{array}{c}\text { OR } \\
(95 \% \mathrm{CI}) \\
\end{array}$} \\
\hline BBL & $\mathrm{n}$ & $\%$ & $\mathbf{n}$ & $\%$ & & & \\
\hline BBLR & 54 & 55,1 & 44 & 44,9 & 98 & 1000,000 & 4,01 \\
\hline $\begin{array}{l}\text { Tidak } \\
\text { BBLR }\end{array}$ & 15 & 23,4 & 49 & 76,6 & 64 & 100 & $(1,99-8,09)$ \\
\hline Total & 69 & 42,6 & 93 & 7,4 & 162 & 100 & \\
\hline
\end{tabular}

Berdasarkan hasil analisis di dapatkan bahwa anak yang memilik riwayat BBLR dalam katagori sangat pendek yaitu sebanyak 54 orang $(55,1 \%)$, dan sebagian kecil anak dengan riwayat tidak BBLR dalam kategori sangat pendek $(23,4 \%)$, dengan nilai $\mathrm{OR}=4,01$ (95\% CI: 1,99 - 8,09), yang artinya anak yang mempunyai riwayat BBLR mempunyai risiko
4,01 kali lebih besar menjadi sangat pendek dibandingkan dengan anak yang lahir tidak BBLR. Setelah dilakukan uji hipotesis dengan metode chi square diperoleh nilai p 0,000 ( $<$ < $0,05)$ yang artinya ada hubungan antara berat badan lahir dengan kejadian stunting pada balita di wilayah kerja Puskesmas Gunungsari Kabupaten Lombok Barat.

\section{Pembahasan}

Penelitian ini dilakukan untuk mengetahui hubungan antara berat badan lahir bayi dengan kejdian stunting pada balita. Di wilayah kerja Puskesmas Gunungsari dengan jumlah sample sebanyak 162 balita. Berdasarkan hasil analisis menunjukkan bahwa terdapat hubungan yang bermakna antara riwayat BBLR dengan kejadian stunting di wilayah kerja Puskesmas Gunungsari Kabupaten Lombok Barat didapatkan nilai $\mathrm{p}$-value $=0,00$, dengan nilai odds ratios 4,01 yang artinya yaitu 4,01 kali berisiko mengalami stunting pada kategori sangat pendek dibandingkan dengan anak yang mempunyai riwayat tidak BBLR. Hal ini sejalan dengan penelitian yang dilakukan oleh Nasution [8], menunjukan bahwa terdapat hubungan antara BBLR dengan kejadian stunting pada anak usia 6-24 bulan yaitu 5,6 kali lebih tinggi mengalami resiko kejadian stunting pada anak dengan riwayat BBLR dibandingkan anak yang lahir dengan berat badan normal. Begitu pula dengan penelitian Rahayu [9], anak yang mengalami stunting berhubungan dengan riwayat BBLR berpeluang 5,87 kali lebih tinggi untuk mengalami stunting. Kejadian ini terjadi karena bayi yang lahir dengan BBLR sejak dalam kandungan sudah mengalami retardasi pertumbuhan intrauterine dan dapat berlanjut sampai usia selanjutnya setelah dilahirkan yaitu pertumbuhan dan perkembangan lebih lambat dari bayi yang dilahirkan normal dan sering gagal menyusul tingkat pertumbuhan yang seharusnya dicapai pada usia setelah lahir.

Hasil penelitian ini juga sejalan dengan penelitian yang dilakukan oleh Fitri [10] yang 
menyatakan bahwa berat badan lahir memiliki hubungan dengan kejadian stunting dimana bayi yang berat badan lahir rendah beresiko 1.665 kali mengalami stunting dibandingkan dengan bayi yang lahir normal. Oktarina dan Sudiarti [11] juga mendukung dalam penelitiannya yang menyatakan bahwa balita yang BBLR memiliki resiko menjadi stunting sebesar 1,7 kali dibanding balita dengan berat normal.

Penelitian ini sejalan dengan penelitian yang dilakukan oleh Putra tentang kejadian stunting pada anak usia 12-60 bulan di wilayah kerja Puskesmas Paud pada tahun 2015, dimana didapatkan p-value 0,049 yang menunjukan bahwa terdapat hubungan antara BBLR dengan kejadian stunting. Penelitan yang dilakukan oleh Nasution [8], di Yogyakarta juga menunjukan hal serupa, BBLR memiliki hubungan yang signifikan terhadap kejadian stunting pada anak usia 6-24 bulan.

Pada penelitian ini juga menemukan bahwa kejadian stunting lebih banyak terjadi pada balita dengan jenis kelamin laki-laki, usia diatas 23 bulan, dan balita yang lahir dengan berat badan rendah, hasil ini juga ditemukan oleh peneliti Torlesse et al [12] dan Chirande et al [13].

Penelitian menunjkan bahwa kejadian stunting lebih banyak terjadi pada jenis kelamin laki-laki, hal yang sama juga hamper terjadi di seluruh dunia seperti yang di temukan oleh ditemukan oleh Mzumara et al [14]. Menurut Chirande et al [13] mengatakan bahwa perbedaan jenis kelamin berkaitan dengan perilaku masyarakat misalnya lebih cenderung menyukai anak peremepuan selain itu juga secara epidemiologis menyatakan bahwa anak laki-laki lebih rentan terhadap morbiditas.

Pada penelitian ini menemukan bahwa balita usia diatas 23 bulan cendrung berisiko mengalami stunting. Hal ini juga ditemukan pada penelitian yang dilakukan oleh Torlesse et al [12] dan Chirande et al [13]. Balita usia diatas 23 bulan cenderung mengalami stunting dikarenakan balita usia ini mendapatkan asupan makanan yang kurang atau tidak sesuai selama proses penyapihan Mittal et al [15].

Penelitian ini juga menemukan bahwa kejadian stunting pada balita lebih banyak terjadi pada balita dengan berat badan lahir rendah $(61,1 \%)$. Hasil penelitian ini juga di dukung oleh penelitian Ardiyah [16] yang menyatakan bahwa balita yang BBLR yang memiliki resiko menjadi stunting lebih besar dibanding balita yang lahir dengan berat normal. Penelitian lainnya yang dilakukan oleh Mbuya [17] menemukan bahwa balita dengan berat lahir rendah cenderung mengalami keterlambatan pertumbuhan dibandingkan dengan balita yang lahir dengan berat badan normal.

Faktor risiko terjadinya stunting pada anak disebabkan oleh beberapa hal seperti anak yang tidak mendapatkan asupan ASI yang adekuat, pendidikan orang tua yang kurang, anak-anak yang lahir dikeluarga miskin, anak-anak dengan keluarga yang memiliki latar belakang kesehatan rendah, anak-anak dengan keluarga yang memiliki akses ke pelayanan kesehatan rendah, dan anak-anak dengan ibu yang jarang memeriksakan kehamilannya [12].

\section{KESIMPULAN}

Berdasarkan hasil penelitian yang dilakukan di wilayah kerja Puskesmas Gunungsari Kabupaten Lombok Barat tahun 2019 dapat di simpulkan sebagai berikut: 1) Kejadian stunting sebagian besar berada pada katagori pendek, 2) Berat badan lahir sebagian besar Berat Badan Lahir Rendah (BBLR), 3) Ada hubungan antara berat badan lahir dengan kejadian stunting pada balita di wilayah kerja Puskesmas Gunungsari Kabupaten Lombok Barat.

Hasil dari penelitian ini diharapkan dapat memperkaya pengembangan ilmu khususnya ilmu keperawatan anak dan dapat melakukan kegiatan pengabdian masyarakat untuk memberikan edukasi dan pemahaman 
tentang stunting dan faktor penyebab stunting.

Bagi Peneliti Selanjutnya, diharapkan melakukan penelitian lebih lanjut pada variabel lain yang dapat mempengaruhi terjadinya stunting seperti faktor ibu, janin, lingkungan yang berpengaruh pada kejadian

\section{DAFTAR PUSTAKA}

[1] Depkes RI. (2010). Profil Kesehatan Indonesia. Jakarta: Depkes RI

[2] Kurniasih. (2010). Sehat dan Bugar Berkat Gizi Seimbang. Jakarta : PT Gramedia.

[3] UNICEF, (2016).Stunted Pada Balita. Public Health.

[4] Dikes NTB. (2018). Data Stunting pada Balita di NTB. Mataram:Dikes NTB

[5] Kemenkes RI. (2013). Riset Kesehatan Dasar; RISKESDAS. Jakarta: Balitbang. Kemenkes RI.

[6] Nadiyah, Briawan D, Martianto D. (2014). Faktor Risiko Anak Stunting Pada Anak Usia 0 - 23 Bulan Di Provinsi Bali, Jawa Barat, Dan Nusa Tenggara Timur. Jurnal Gizi dan Pangan

[7] Arifin, Zainal. (2012). Penenlitian Pendidikan Metode dan Paradigma Baru. Bandung: Remaja Rosda Karya

[8] Nasution, Nurdiyati dan Huriyati (2014). Pengaruh BBLR terhadap kejadian stunting pada anak usia 12-60 bulan diwilayah kerja Puskesmas Pauh pada tahun 2016.

[9] Rahayu, Atikah. Dkk (2017). Riwayat Berat Badan lahir Dengan Kejadian Stunting pada anak Usia Bawah Dua Tahun. DOI: http;//dx.doi.org/10.21109/kesmos.v10i2. 882

[10] Fitri. (2012). Berat Lahir Sebagai Faktor Dominan Terjadinya Stunting Pada Balita (12-59 bulan) di Sumatera (Analisis Data Riskesdas 2010). Universitas Indonesia

[11] Oktarina dan Sudiarti, (2014). Hubungan berat badan lahir dengan kejadian stunting.

[12] Torlesse et al. (2016). Determinants of stunting in Indonesian children: evidence from a cross-sectional survey indicate a prominent role for the water, sanitation and hygiene sector in stunting reduction.
BMC Public Health (2016) 16:669. DOI 10.1186/s12889-016-3339-8

[13] Chirande et al.(2015). Determinants of stunting and severe stunting among under-fives in Tanzania: evidence from the 2010 cross-sectional household survey. BMC Pediatrics (2015) 15:165. DOI 10.1186/s12887-015-0482-9

[14] Mzumara, B., Bwembya, P., Halwiindi, H. et al. (2018). Factors associated with stunting among children below five years of age in Zambia: evidence from the 2014 Zambia demographic and health survey. BMC Nutr 4, 51. https://doi.org/10.1186/s40795-018-02609

[15] Mittal et al. (2007). Effect of maternal factors on nutritional status of 1-5-yearold children in urban slum population. Indian J Community Med

[16] Ardiyah, FO, Rohmawati, N., Ririyanti, M. (2015). Faktor-faktor yang mempengaruhi Kejadian Stunting Pada Anak Balita di Wilayah Pedesaan dan Perkotaan. E-Jurnal Pustaka Kesehatan. Vol: 3 (1)

[17] Mbuya, M., Chideme, M., Chasekwa, B., Mishra, V. (2010). Biological, Social, and Environmental Determinants of Low Birth Weight and Stunting among Infants and Young Children in Zimbabwe, in Zimbabwe working paper No. 7. Calverton: ICF Macro; p. 39 